\title{
Transposition
}

Musique et Sciences Sociales

\section{Understanding Music and Sexuality through Ethnography: Dialogues between Queer Studies and Music}

\section{Esperanza Miyake}

\section{OpenEdition}

\section{Journals}

Electronic version

URL: http://journals.openedition.org/transposition/150

DOI: $10.4000 /$ transposition. 150

ISSN: $2110-6134$

Publisher

CRAL - Centre de recherche sur les arts et le langage

\section{Electronic reference}

Esperanza Miyake, « Understanding Music and Sexuality through Ethnography: Dialogues between Queer Studies and Music », Transposition [Online], 3 | 2013, Online since 01 March 2013, connection on 30 April 2019. URL : http://journals.openedition.org/transposition/150 ; DOI : 10.4000/ transposition. 150

This text was automatically generated on 30 April 2019.

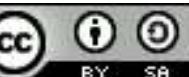

La revue Transposition est mise à disposition selon les termes de la Licence Creative Commons Attribution - Partage dans les Mêmes Conditions 4.0 International. 


\title{
Understanding Music and Sexuality through Ethnography: Dialogues between Queer Studies and Music
}

\author{
Esperanza Miyake
}

Three girls link their arms, clicking their heels as they giggle their way towards a little corner just off Canal Street. Below an illuminated poster with female stick figures crayoned in, dancing in a burst of colours, stands a burly woman dressed as no other can be dressed - she's a bouncer, a protector, a vigilante and a no-messer. The girls go in, flirty and showy, waving their hands and leaning against each other for support. And for that brief moment when the door opens, the street is filled with sounds of techno emanating from within, a vibration riding upon waves of drunken laughter. The door shuts and the noise is dampened once again by the cold night air. I can smell Manchester in the air, a mix of slightly rank canal water and that strange beer-toilet-cleaner-cigarette smell that often fans out of pubs. With my left hand I check my tape-recorder in my pocket, I take one last deep breath. This is it, I've got to go in. ${ }^{1}$

I am not even carrying my tape-recorder, I don't want to jinx things, I don't want Vanilla. I pace around for ages outside Manto Bar on Canal Street because I'm early you can do this. You've got nothing to lose. If it's not good, you would've at least sung - c'mon you'll feel better afterwards for it. 10mins to go, I impatiently and nervously enter Manto and find a pretty queer boy vacuuming the floor and bar staff setting up for the evening. I ask the bartender where the choir sings and she points towards the ceiling with a dish rag. One step at a time, I walk up their spirally staircase and finally reach a set of double doors: I have stepped into my field. ${ }^{2}$

1 I moved to Manchester in the summer of 2003, a queer musician, a lost researcher trying to whistle my way around the city. All I knew back then was that I wanted to investigate the relationship between music and sexuality, a connection that seemed so obvious and natural yet also proving to be frustratingly elusive as an academic subject matter.

2 The vast majority of literature on music and sexuality at the time in early the 2000s queer theory and queer musicology had gained momentum by then - focused primarily 
on issues surrounding gender and/or the engenderedness of a musical performance or a piece. ${ }^{3}$ Alternatively, work concentrated on the "sex" of sex-uality, ${ }^{4}$ where music involved some kind of erotic exchange. Within this configuration, the idea of sexuality becomes either conflated with notions of gender, or becomes bound to the erotic. Theoretically, I wanted to move away from both of these routes and find other ways to think about the music-sexuality relationship, particularly in relation to queer theory which I wanted to be more than just about gender and the erotic.

Furthermore, in the early 2000s, there seemed to be very little ethnographic research conducted on musicians in relation to queer theory and sexuality. ${ }^{5}$ Methodologically, I wanted to move towards empirical research to address what seemed to be a relatively unexplored area of investigation, particularly within the field of queer musicology. Determined, I went in search of my field. In the winter of 2003, I began interviewing lesbian DJs and clientele in the city's openly lesbian bar located in the Gay Village, Vanilla, only to find myself trapped in precisely what I wanted to avoid. From drag kings dancing to music, to being chatted up by potential informants; the field that I confronted seemed to be an engendered and eroticized battleground of homosexual social interaction. Was music and sexuality, after all, really just about engendered performances and/or the eroticization of music?

Rather fortuitously around the same time, I encountered the Manchester Lesbian and Gay Chorus (MLGC), a group of over 100 members of the local LGBT community who sang and performed together in and around Manchester. ${ }^{6}$ Upon finding them in Manto Bar - a venue located a couple of buildings away from my initial lesbian bar on Canal Street - I joined the group immediately and so began my two-year ethnography with them between 2003 and 2005. Looking back on this project, I realize that my research was not only about exploring the relationship between music and sexuality but also about engaging with ethnography as a form of both theory and methodology. This article thus explores ethnography as a queer mode of analyzing music, one which can not only give us a deeper understanding of the music-sexuality relationship, but one which I argue can bring queer theory and music closer together. My intention here is to encourage more scholars to turn to ethnographic research as both a mode of "data-gathering" and a theoretical tool when engaging with queer theory in relation to the study of music.

\section{Queering Ethnography}

5 In his empirical study of gay and lesbian choruses around USA (1994), ${ }^{7}$ sociologist Paul Attinello undertook quantitative research methods in the form of questionnaires. ${ }^{8}$ However, the reason he gives for not undertaking qualitative methods are the following:

Unfortunately many of the more important or interesting points are in areas where it is difficult to quantify or even to extract responses. The defensiveness of subcultures is a serious problem, and the powerful human desire to avoid examination of one's deeper motives constantly gets in the way of open discussion of these areas. ${ }^{9}$

Whilst the "defensiveness of subcultures" can indeed pose a challenge during fieldwork research, I want to argue that perhaps the problems which Attinello refers to might arise from an overemphasis on the "sex" of sex-uality and/or the defining of sexual identity as a choice in sexual orientation. That is, at a time when being a member of the LGBT community was still subject to social stigmatization and/or because sex-uality is a 
"personal" issue which people might not wish to discuss, it is understandable that there might be a certain level of general "defensiveness" surrounding subcultures'. This is not to say that "sexuality" or "sexual identity" should not or do not include these definitions. I am suggesting that we include but also move beyond these definitions and begin to analyze how music and sexuality can cross over as a social interaction, and what is more, to use ethnographic research as a way of identifying the points at which they cross over.

With the changes in legislation surrounding LGBT rights since the mid- to late- 2000s in Great Britain, not to mention the interrelated and increasing "queerification" of British culture, the term "queer" itself has changed in meaning since its initial inception as a politics and theory relating to disruption, intervention and anti-normativity. Since I conducted my ethnography, there has been a growing body of work focusing on not only the relationship between music and sexuality, ${ }_{10}^{10}$ but also the use of queer theory and ethnography. ${ }^{11}$ These are primarily concerned with using queer theory as a way of: a) challenging normative practices in anthropology and ethnography, particularly in relation to subjugated knowledges, ${ }^{12}$ b) thinking about multiple subjectivities within and without the field $;{ }^{13}$ c) studying the "queer subject"; ${ }^{14} d$ ) conducting empirical research into social practices defined by pleasure and desire. ${ }^{15}$ In this light, "queer" for me was not necessarily about challenging disciplinary practices (I was lucky to have been in a Women's Studies department which encouraged my engagement with queer theory). Nor was "queer" part of a means of studying and documenting erotic practices within the LGBT community in Manchester. What it was however, was a way of thinking about multiple subjectivities within the field as a ethnographic chorister whose singing voice enabled my embodiment of the field. Queer methodology was also part of my desire to document the process of LGBT musicians making music together in everyday life.

There are two authors whom I would like to refer to at this point, both of them use ethnographies to explore the conditions which organise and enable the social enactment of music in everyday life: Tia DeNora's Music in Everyday Life, and Ruth Finnegan's Hidden Musicians: Music-Making in an English Town. ${ }^{16}$ DeNora's work investigates a wide range of social activities detailing how music is "pressed into action"17: what music does during aerobics classes; interviewees' accounts on their use of music to set and changing their mood; music therapy; and the use of music as a consumerist strategy in retailing. For DeNora, music is thus a backdrop, a "dynamic material of structuration"18 which individuals use according to their emotional, practical, or psychic needs. DeNora's functionalist approach to music means her understanding of "music pressed into action" is less about the sociality involved in music, instead, it is more about the utilitarian functionality of music for individuals to order their actions in their social lives.

In contrast to DeNora's work, sociologist Ruth Finnegan's Hidden Musicians: Music-Making in an English Town is dedicated specifically to the investigation of the sociality of music, where music is regarded as being inseparable from social interaction for it is "a matter of active collective practice rather than just passive mass-controlled consumption of the solitary contemplation of musical works". ${ }^{19}$ Basing her research on participant observation, collecting of leaflets/posters/newsletters, phone interviews as well as talking to some key figures on an informal basis in various settings in the town of Milton Keynes, Finnegan examines how different individuals are linked 'not just by shared views or emotions but by social practices. People may or may not feel a sense of closure or separation from others in specific situations, but what does define their habitual musical pathways are their shared and purposive collective actions' (emphasis Finnegan's). ${ }^{20}$ For 
Finnegan, music is not so much "pressed into action" as DeNora postulates, music is the action, it is in effect a social practice in itself.

DeNora and Finnegan have very different understandings of what "music in action" consists of: the former analyzing the use of music for the construction of everyday social life, the latter analysing sociality as constructing music in everyday life. The position I took during my fieldwork research was somewhere between the two authors. On the one hand, I was interested in music as being "pressed into action" by lesbian and gay musicians. Here, I was concerned with how musical action might relate to queering as an action, a verb reflecting a queer politics of intervention as referred to earlier. On the other hand, I was also interested in analysing lesbian and gay music-making to understand how queerness is read and articulated in music.

11 In DeNora's interviews, her subjects are treated separately with no particular connection made between them. At the other end of the spectrum, Finnegan does not analyse her interviews at the level of depth DeNora does but instead tends to collapse individual accounts into one general grouping, such as "the rock bands" or "the musicians at the pub". For Finnegan, the musicians' accounts are about the overall continuum of events and people being organised through their music-making processes. My own position was and is to embrace both DeNora's and Finnegan's approaches to their interviews: to analyse how a lesbian and gay individual's account - and I include myself and my observations here - is unique, and to also regard it as part of a collective story. Finnegan argues that music is "defined in different ways among different groups, each of whom have their own conventions supported by existing practices and ideas about the right way in which music should be realised". ${ }^{21}$ By examining a group of lesbian and gay musicians' "ideas about the right way in which music should be realised" an ethnography can thus explore how queerness might be read and articulated as part of a collective social process, and what this says about lesbians and gay musician today. In other words, the study of lesbian and gay musicians as part of the "different groups" remains largely unexamined: what are the social values and social conventions that they hold in common, and how and where is music configured within this process?

\section{Becoming a Queer Ethnographic Chorister: singing my way into fieldwork}

12 Finnegan explains how the amateur musicians she studies are hidden in two ways: they rarely receive scholarly attention, and their practices are part of a large network of local music-making of which those outside are unaware. These reasons are why Finnegan conducted her ethnography, "to reveal something of a reality that has too often remained unnoticed". ${ }^{22}$ I share the same drive as Finnegan in wanting to conduct an ethnographic study to expose the hiddenness related to amateur and lesbian and gay musicians in everyday life. For "hidden" within a lesbian and gay context has implications of being "hidden in the closet", ${ }^{23}$ both within academic discourse and in life. ${ }^{24}$ I have another important, politically-driven reason behind my using an ethnography and so add a third definition to Finnegan's Hidden Musicians: the doubly hidden lives of lesbian and gay musicians.

13 As mentioned earlier, I conducted an ethnography of the MLGC, a group of lesbian and gay singers making music in the city of Manchester. I engaged in participant observation 
by joining the choir as a soprano and later as a tenor, as well as conducting qualitative interviews with 14 members (9 women, 5 men), between the ages of 25-65. The ethnographic material gathered for my project presented different social contexts in which to understand the relationship between music and sexuality: from group discussions on music, individual reflections on their relationship music and the choir itself, different kinds of musical events they choose to participate in, incidents that arise during rehearsals or performances. By analysing their everyday life musical activities both as a group and as individual members, my work drew out what kind of factors which might include issues surrounding gender and the erotic - bring the concepts of music and sexuality together. By taking an interdisciplinary approach to the material, the aim of my ethnography was to also provide a basis for a dialogue between musicology, queer theory, sociology of music, popular and (sub)cultural studies of music.

I was concerned with using fieldwork to unearth what hidden musical practices - in the case of this project, choral singing - might be falling outside of sociological, cultural and subcultural studies of music. In being amateur musicians, they also do not get the attention that other more renowned lesbian and gay composers might within queer musicology. But what is hiding them? Where are they? Why are hidden?

In Music in Everyday Life, DeNora carries out her fieldwork in metropolitan areas and small towns in United States and United Kingdom. Through a combination of participant observation and interviews conducted with women from these areas, DeNora investigates "how real people actually press music into action in particular social spaces and temporal settings". ${ }^{25}$ I borrow DeNora's term, "ground level" to describe two important aspects of this article. Firstly, I am referring to the literal ground, street level of the Gay Village in Manchester, where I first begun my investigations. How and where does music materially ground sexuality? Secondly, by "ground level" I am also referring to the large body of existing literature that grounds the idea of sexuality and music within the realms of erotic sociality. For reasons which will become apparent in due course, my fieldwork moves away from the notion of 'ground level, in both senses of the term.

In the following, I want to first provide an account of the initial "failed" fieldwork I carried out at the ground level in Canal Street, the main area in the Gay Village of Manchester. The discussion will centre around Vanilla, a lesbian bar, where at first I attempted to investigate how music and sexuality were crossing over as part of lesbian sociality. I shall highlight some of the practical problems which emerged from this initial research because these "failings" provide a clue into why music and sexuality have been so predominantly conceptualised through the erotic dynamic, within which questions of desire and pleasure are configured.

The latter half of this article will explain how and why participant observation and qualitative interviews enabled me to become part of another field. Here I shall be referring to the idea of the queer ethnographic chorister as a figure who brings ethnographic, musical, and lesbian and gay social practices together. The second part of the discussion will focus on my some of the material gathered during my time with the MLGC: away from both the physical and theoretical "ground level" of an eroticized field. No matter what venues they choose in the Village, the MLGC's rehearsals always occur upstairs and away from the main ground level of Canal Street. The MLGC's spatial separation from ground-level means their kind of musical activities are hidden from scholars and the rest of Canal St, both of which centralise the erotic aspects of sexuality and music. Reflecting and building upon Finnegan's Hidden Musicians, I shall therefore 
explain how the MLGC provided an ideal ground from where to study the relationship between music and sexuality: as removed from the directly eroticized context of a place like Vanilla; away from the physical and theoretical ground-level of the music-sexuality relationship.

\section{At Ground Level: Canal Street}

The bouncer looks me in the eye. I feel like I'm passing through airport security, or a teenager wanting to buy booze. If only I had a girlfriend now, or even a friend who was a girl - whatever, just not alone. The bouncer catches my eye. One second passes and I can see she is trying to work out whether I'm a straight woman or a femmy dyke. She nods, gives me a proof card and I'm in. ${ }^{26}$

I began to undertake fieldwork and the most obvious - or the loudest and thus most immediately present - place to go seemed to be the Gay Village. I chose Vanilla, the main lesbian bar situated just off Canal Street with the intention of interviewing their clientèle and perhaps some of their DJs about their relationship to music. Feminist ethnographer Amanda Coffey argues that because of the embodied nature of fieldwork, the fieldworker's body as a participatory body is an 'ethnographic body', a corporeal entity which must place itself in relation to the peopled field of investigation: appearance, conduct, emotional reaction, communication; all forms of body management which make the ethnographer's body into an "ethnographic body". ${ }^{27}$ Analysis of the ethnographic body's management can be a way of examining the field itself, what kind of social codes are organising the people within a given location. Following Coffey's argument, I shall briefly discuss the way I managed myself within Vanilla to reflect upon one definition of sexuality, and how music is pressing it into action.

I initially placed posters calling for anyone willing to be interviewed up on Vanilla's notice boards, alongside advertisements for dildos, personals, glamour photo-shoots: already tell-tale signs of a place defined largely through the erotic; even the name "Vanilla" and its special $£ 500$ machine pumping out vanilla essence are allusions to lesbian vanilla sex. As can be seen in the poster (Fig. 1), the title of the night ("CLIMAX"... live countdown and explosion!), its tongue-and-cheek reference to New York's sex joints (Girls! Girls! Girls!), the sexualised image of the alluring DJ who returns our gaze with a becoming finger and exposed torso: these are all representations of how Vanilla's sense ${ }^{28}$ economy is defined by sex and the promise of erotic exchange. How is music configured within this environment? 


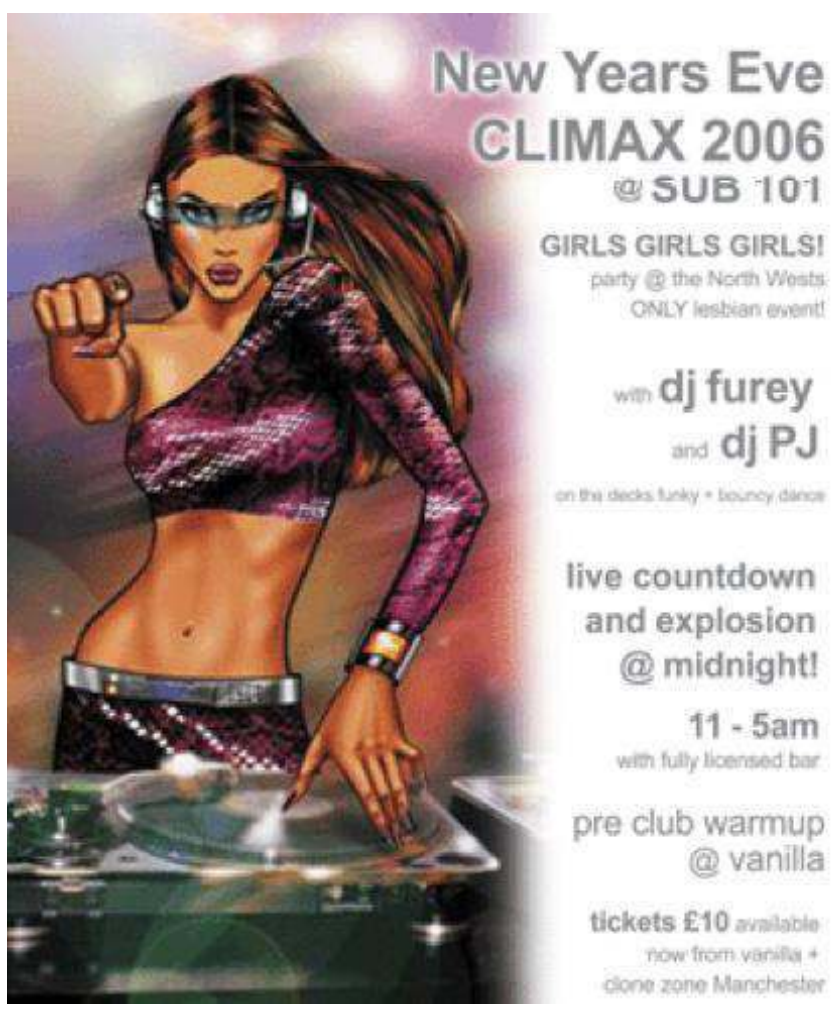

fig 1.

Poster advertising a special night at Vanilla (reproduced with permission).

Subcultural Capital and her work investigates how DJs have gained 'subcultural capital within the club/dance scene, where they gain celebrity status, complete with fans: "DJs are artists in the construction of a musical experience", ${ }^{30}$ she writes; but in the case of Vanilla and its DJs, I would argue that the DJs were artists in the construction of a lesbian experience in Manchester first and foremost by not only providing their beats, but providing themselves as "lesbian DJs" (DJing is a predominantly male world), potential subjects of desire. ${ }^{31}$ One of the DJs stated, "my sole concern is to fill the dance floor with lots of girls having fun and if that happens I consider it a good night" (DJ Lin); another DJ told me how she aims to create a "sexy buzz" through the music she plays which 'rubs off on people as they dance, literally' (DJ Harvey). These statements indicate how within this context, music fulfils a functional purpose for the DJs in creating an erotically charged environment. In his work on clubbing and dancing, Malbon argues that to dance is not only to experience music as time, but to also experience time as music: the DJs in Vanilla thus musicalize a lesbian temporarily, one which was motionally materialised through dance propelled by an erotic drive.

One of the greatest practical problems I faced at the time was how I myself as a researcher had to respond to music within the overtly eroticized space: 


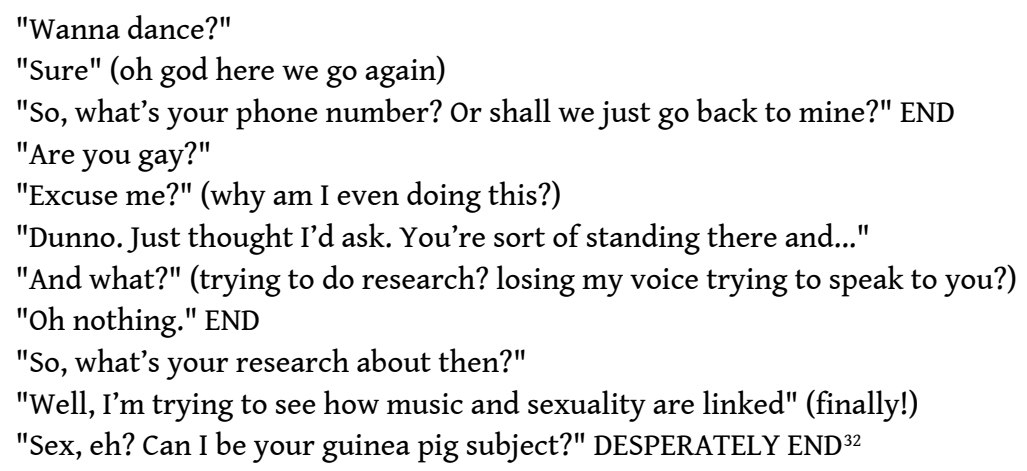

Spoken words became swallowed up as part of an erotic exchange circulating within the sonorous economy of Vanilla. All questions I received were ultimately for the purposes of flirting, and even the utterance of academic research melted into such an interaction (last example). Within this context, I either had to dance or adopt a more scopic and observational position. Yet my ethnographic gaze ${ }^{33}$ too, was eroticized, where my observations were interpreted as part of lesbian cruising practices: a form of voyeurism within a sex-ualized field. Whilst this is not a problem in itself, my inability to reconcile these two gazes stemmed from my reservations about ethical issues regarding the relationship between researcher and their field. ${ }^{34}$

Empirical research into subcultures ${ }^{35}$ covers a range of practical research problems such as confronting drunkenness, witnessing and recording supposed 'illegal' activities like prostitution, ${ }^{36}$ drug-taking, cottaging, ${ }^{37}$ gaining trust from those who are suspicious of institutionalised forms of interaction. ${ }^{38}$ Humphrey's ${ }^{39}$ and Bolton's work ${ }^{40}$ embody their sexualised field by becoming an erotic subject themselves, where their ethnographic practices are part of the gay men's erotic sociality they are studying.

As my experiences in Vanilla and the remarks made by the DJs would indicate, music proves to be a functional part of a lesbian club culture ${ }^{41}$ which operates through a sense economy based on the erotic exchange of sexuality. Furthermore, I am asked whether I am gay based on my "sort of standing there. In other words, my lesbian credibility seems to be based on the level of corporeal" participation within the auditory field: either dance or be danced at, and unless I was willing to use my body for "listening that prioritises the motional understanding of music", ${ }^{42}$ I ceased to exist as a lesbian, as a researcher, and as a clubber in the eyes of those in Vanilla.

I regard my experiences in Vanilla as relating not just to the issue of body management within a field, but also an indication of how the erotic is what often underlines queer sociality: "for queers eroticism is the basis of community" write Bell and Binnie in their work on sexual citizenship and the city. ${ }^{43}$ Perhaps this is the reason why not only is there a prevalence within queer theory to theorise sexuality through the erotic, but music too: queer cultural politics is so strongly tied to the politics of the social, and vice versa, that both musical practices become instrumental or even bridge the gap between the cultural and social politics of sexuality. This is particularly the case within subcultural spaces like Vanilla, where music facilitates the circulation of eroticized desire and choreographs social relations based on the consumption and production of sex-uality. 


\section{Hidden away upstairs, above ground level: Manchester Gay and Lesbian Chorus, and a choral ethnography} know people through conversation), I had no problems in approaching people unlike in Vanilla. Whilst the question of sex might be one aspect of the MLGC's social interactions, the prime reason for the members' presence was to make music with other lesbian and gay men. Even the physical setting of rehearsals and performances ensure that music is what brings people together, not sex. Whilst the bar is open during rehearsals, it is used for refreshment rather than socialization purposes and in fact, members are discouraged from talking during rehearsals. Despite being part of the Village as a designated lesbian and gay area, the MLGC are positioned away from the main ground of eroticised queer spaces: thus an ideal location for this project. The following will provide an account into how and why I engaged in participant observation and conducted a series of qualitative interviews with members of the MLGC.

\section{Ethnographic chorister. singing and embodying the field}

One of the main problems I faced in Vanilla was my failure to embody the field through social interaction - adopting suitable codes of behaviour - rendering me silent and invisible. In being part of the MLGC's organised choral sound - not just passively but actively as a soprano - my own singing voice positioned me within the field. In other words, my singing and occupying a space in the soprano section meant I was an active participant and no longer a voyeur of the scene: I became an ethnographic chorister conducting participant observation (or singing) within the auditory and ethnographic field. Here, participant observer and chorister are one through the voice, where both positions are dependent on being part of the existing organised choral framework. Furthermore participant observation is a method which involves a rather tenuous and precarious state of being both part of and yet analytical of a field. In the Cambridge Companion to Singing, Heikki Liimola's work discusses the techniques to choral singing in particular and advises choristers to "be conscious that you are a line of singers trying to act as one: breathe and articulate together, think yourself into the voice of the person next to you". ${ }^{4}$ The musical director similarly would tell us often to look at each other (indicated by an index finger to the eye), to smile at each other, and most importantly to listen to each other in order to create the right balance between the voices. Previously in Vanilla, music organised social relations based on the circulation of eroticised desire. Within this configuration, I argued that all social practices became part of an erotic exchange, and this included my ethnographic practices. In contrast, within the context of the MLGC, the ethnographic voyeurism that I problematised in Vanilla became a matter of musical skill rather as part of a sex-ualised social practice. This is not to say that desire was not part of the configuration: in fact, the pleasure of singing and the desire to be part of the social formation of a lesbian and gay chorus are very much at the heart of my ethnographic practices. 


\section{Telling musical stories: choral accounts} chorus's repertoire (which I was part of) handed out slips of paper requesting members to list songs they felt they wanted the chorus to sing along with reasons why. Seeing these returned pieces of paper made me realise a similar questionnaire for the purposes of my research would probably not give me the level of thought and articulation the same members had expressed during AGMs or informal meetings/ discussions/ debates. For example, in answer to "why would you like the choir to sing your song of choice?" the response was "Cos I like it", a significant felling of words compared to opinions voiced with passion at a different time and place. Therefore, the manner in which I tried to record the more elaborate and passionate opinions by MLGC members was to write down or remember certain points they might have made during a meeting or an AGM, or during a casual conversation at the bar.

I mean I've come out at home, at work, everywhere else... but it doesn't actually affect what you do day-to-day, you get up, you get to work, you see your family, you go to the cinema. But to me, it's making a statement... by being a member of the choir and being proud to be member of the choir. And it... sort of... it's an affirmation every 2 weeks that... yes, I am gay and because I'm gay I'm mixed with these people (Clara, a soprano).

Such "day-to-day" details of lesbian and gay life ("I've come out at home, at work, everywhere else... but it doesn't actually affect what you do day-to-day, you get up, you get to work, you see your family, you go to the cinema") cannot be obtained from participant observation alone.

When I began to listen back to the tapes in order to transcribe the interviews with the members of the MLGC, it occurred to me how the voices telling me the stories of their lives were the same voices which had sung at another point in life. In discussing the question of orality, Michel De Certeau and Luce Giard state, "orality is everywhere, because conversation insinuates itself everywhere, organizing both the family and the street, both work in a business and research in a laboratory". ${ }^{45}$ The voice acts as a sonorous passage which connects and separates the ordinary life outside of the choir, and the musical practices occurring within the choir. So many of my interviews compare the choir against their "ordinary day to day basis" (Tinny) or as "what you do day-to-day" (Clara). Yet the choir is also an "important part of my life" (Charlotte). As Clara's statement would indicate, it is something about the choir as a musical and lesbian and gay group that make it a meaningful place: somehow the choir enables members to articulate a sense of queerness they normally do not articulate, even if they are out. In terms of this project, this music-sexuality cross-over is an ideal field to explore questions of queer, queerness, and queering: the ethnographic analysis attempts to draw such points out from the accounts.

As discussed earlier, DeNora's interviews are treated as individual and unrelated accounts with no connection made between them, whilst Finnegan takes a more generalised approach where the musicians' accounts are part of an overall continuum of events and people being organised through their music-making processes. I stated earlier that my aim was to embrace both DeNora's and Finnegan's approaches to their interviews: to analyse how a lesbian and gay individual's account is unique, and to also regard it as part of a collective story. Here, I am thinking about the concept of collectivity as both a chorus 
and as a queer group, a pluralism of voices. In other words, I approach my qualitative interviews as individual accounts by lesbians and gay musicians who are, at the same time, members of a collective chorus. I am interested in how the individual translates to communal, and by extension, how lesbian and gay translates to queer, if at all. What kind of factors in music bring lesbian and gay musicians together, as part of a "shared cultural understanding" (John)?

And I went to choir just to see him (Chongwei, Chair of MLGC) rehearse [...] I felt like - even though I'd never sung with them - I felt I was part of the choir, and I was sat down watching them! Oh, that's amazing that! (John, a Bass).

(1)

factors which bring music and sexuality together, which in turn can enable us to analyze the social, cultural, and political implications of such a convergence. Through the documentation and analyses of how LGBT musicians make music together - particularly those everyday life practices surrounding music - ethnographies can thus provide a means of understanding the music-sexuality relationship beyond questions of gender and the erotic by grounding theories at a point where music and sexuality cross over as part of a social interaction. That is, ethnographies can loosen what can be a restrictive connection between music and the idea of "queerness" as being about the subcultural consumption of sexuality/musicality through a form of erotic sociality. In other words, by studying the everyday and "mundane", ethnographies can allow us to reconceptualise ways in which music connects the cultural and social politics of sexuality. Ethnographies can thus bring queer studies and theories on music closer: they can enable us to re-think and open up new ways to think about queer, queerness, and queering music and music-making practices. I hope this article and the research I have conducted thus far will convince more of us queer scholars of music to travel down the ethnographic path of investigation to broaden our understanding of the relationship between music and sexuality, as well as enriching dialogues between queer studies and theories on music. 


\section{BIBLIOGRAPHY}

ABRAHAMS, Roger D., "Ordinary and Extraordinary Experience", in TURNER, Victor W., BRUNER, Edward M. (eds.), The Anthropology of Experience, Urbana, Chicago, University of Illinois Press, 1986, p. 45-72.

ATTINELLO, Paul, "Authority and Freedom: toward a sociology of Gay Choruses", in BRETT, Philip, WOOD, Elizabeth, THOMAS, Gary C. (eds.), Queering the Pitch: The New Gay and Lesbian Musicology, New York, London, Routledge, 1994, p. 315-346.

AUSTERN, Linda, "'No Women Are Indeed': The Boy Actor as Vocal Seductress in Late Sixteenthand Early Seventeenth-Century English Drama", in DUNN, Leslie C., JONES, Nancy A. (eds.), Embodied Voices: Representing Female Vocality in Western Culture, Cambridge, Cambridge University Press, 1994, p. 83-102.

BARKIN, Elaine, HAMESSLEY, Lydia (eds.), Audible Traces: Gender, Identity, and Music, Zurich, Carciofoli, 1999.

BELL, David, BINNIE, Jon, Sexual Citizen: Queer Politics and Beyond, Cambridge, Oxford, Malden, Polity Press, 2000.

BOELLSTORFF, Tom, "Queer Techne: Two Theses on Methodology and Queer Studies", in BROWNE, Kath, NASH, Catherine J. (eds.), Queer Methods and Methodologies: Intersecting Queer Theories and Social Science Research, Farnham, Burlington, Ashgate Publishing, 2010, p. 215-230.

BOLTON, Ralph, "Tricks, friends and lvoers: Erotic Encounters in the Field", in KULICK, Don, WILLSON, Margaret (eds.), Taboo: Sex, Identity, and Erotic Subjectivity in Anthropological Fieldwork, London, New York, Routledge, 1995, p. 140-167.

BRETT, Philip, WOOD, Elizabeth, THOMAS, Gary C. (eds.), Queering the Pitch: The New Gay and Lesbian Musicology, New York, London, Routledge, 1994.

BROWN, Michael P., Closet Space: Geographies of Metaphor from the Body to the Globe, London, New York, Routledge, 2000.

BROWNE, Kath, NASH, Catherine J. (eds.), Queer Methods and Methodologies: Intersecting Queer Theories and Social Science Research, Farnham, Burlington, Ashgate Publishing, 2010.

COFFEY, Amanda, The Ethnographic Self: fieldwork and the representation of identity, London, California, New Delhi, Sage Publications, 1999.

COOK, Susan C., TSOU, Judy S. (eds.), Cecilia Reclaimed: Feminist Perspectives on Gender and Music, Illinois, Illinois University Press, 1994.

DAME, Joke, "Unveiled Voices: Sexual Difference and the Castrato", in BRETT, Philip, WOOD, Elizabeth, THOMAS, Gary C. (eds.), Queering the Pitch: The New Gay and Lesbian Musicology, New York, London, Routledge, 1994, p. 139-153.

DE CERTEAU, Michel, GIARD, Luce, MAYOL, Pierre, The Practice of Everyday Life, Volume 2: Living and Cooking, Trans., Timothy J. Tomasik, Minneapolis, University of Minnesota Press, 1998.

DeNORA, Tia, Music in Everyday Life, Cambridge, Cambridge University Press, 2000. 
DUBERMAN, Martin B., VICINUS, Martha, CHAUNCEY, George (eds), Hidden from History: reclaiming the Gay and Lesbian Past, London, New York, Meridian Books, 1989.

FARRAN, Denise, "'Seeking Susan': producing statistical information on young people's leisure", in STANLEY, Liz (ed.), Feminist Praxis: Research Theory and Epistemology in Feminist Sociology, London, New York, Routledge, 1990, p. 91-102

FINNEGAN, Ruth, Hidden Musicians: Music-Making in an English Town, Cambridge, Cambridge University Press, 1989 rep. 2007.

GORMAN-MURRAY, Andrew, JOHNSTON, Lynda, WAITT, Gordon, "Queer(ing) Communication in Research Relationships: A Conversation about Subjectivities, Methodologies and Ethics", in BROWNE, Kath, NASH, Catherine J. (eds.), Queer Methods and Methodologies: Intersecting Queer Theories and Social Science Research, Farnham, Burlington, Ashgate Publishing, 2010, p. 97-112.

GRIFFITHS, Vivienne, "Using Drama to Get at Gender", in STANLEY, Liz (ed.), Feminist Praxis: Research Theory and Epistemology in Feminist Sociology, London, New York, Routledge, 1990, p. 221-235.

HAGGIS, Jane, "The Feminist Research Process: Defining a Topic", in STANLEY, Liz (ed.), Feminist Praxis: Research Theory and Epistemology in Feminist Sociology, London, New York, Routledge, 1990, p. 67-79.

HALBERSTAM, Judith, In a Queer Time and Place: Transgender Bodies, Subcultural Lives, New York, London, New York University Press, 2005.

HAMMERSLEY, Martyn, What is Wrong with Ethnography?, New York, Routledge, 1993.

HANKIN, Kelly, The Girls in the Back Room: Looking at the Lesbian Bar, Minneapolis, University of Minnesota Press, 2002.

HOLMAN JONES, Stacy, ADAMS, Tony E., "Autoethnography is a Queer Method", in BROWNE, Kath, NASH, Catherine J. (eds.), Queer Methods and Methodologies: Intersecting Queer Theories and Social Science Research, Farnham, Burlington, Ashgate Publishing, 2010, p. 195-214.

HUMPHREYS, Laud, "The Sociologist as Voyeur", in GELDER, Ken, THORNTON, Sarah (eds.), The Subcultures Reader, London, New York, Routledge, 1997, p. 231-245.

JACKMAN, Michael Connors, "The Trouble with Fieldwork: Queering Methodologies", in BROWNE, Kath, NASH, Catherine J. (eds.), Queer Methods and Methodologies: Intersecting Queer Theories and Social Science Research, Farnham, Burlington, Ashgate Publishing, 2010, p. 113-128.

KOESTENBAUM, Wayne, The Queen's Throat: Opera, Homosexuality, and the Mystery of Desire, New York, Vintage Books, 1994.

KONDO, Dorinne K., Crafting Selves: Power, Gender and Discourses of Identity in a Japanese Workplace, Chicago, University of Chicago Press, 1990.

KULICK, Don, WILLSON, Margaret (eds.), Taboo: Sex, Identity, and Erotic Subjectivity in Anthropological Fieldwork, London, New York, Routledge, 1995.

LIIMOLA, Heikki, "Some notes on choral singing", in POTTER, John (ed.), The Cambridge Companion to Singing, Cambridge, Cambridge University Press, 2000.

MALBON, Ben, Clubbing: Dancing, Ecstasy and Vitality, London, New York, Routledge, 1999.

MARKS, Laura U., Touch: Sensuous Theory and Multisensory Media, Minneapolis, Minnesota University Press, 2002. 
McCLARY, Susan, Feminine Endings: music, gender, and sexuality, Minneapolis, University of Minnesota Press, 1991.

McKEGANEY, Neil P., BARNARD, Marina, Sex work on the streets: prostitutes and their clients, Buckingham, Open University Press, 1996.

MORRIS, Mitchell, "Reading as an Opera Queen", in SOLIE, Ruth A. (ed.), Musicology and Difference: Gender and Sexuality in Music Scholarship, Berkeley, California University Press, 1993, p. 184-200.

MULVEY, Laura, Visual and other Pleasures, Basingstoke, Macmillan, 1989.

POLAND, Fiona, "Breaking the Rules: Assessing the Assessment of a Girls' Project", in STANLEY, Liz (ed.), Feminist Praxis: Research Theory and Epistemology in Feminist Sociology, London, New York, Routledge, 1990, p. 159-171.

POLSKY, Ned, "Research Method, Morality in Criminology", in GELDER, Ken, THORNTON, Sarah (eds.), The Subcultures Reader, London, New York, Routledge, 1997, p. 217-230.

PUGH, Anne, "My Statistics and Feminism - A True Story", in STANLEY, Liz (ed.),Feminist Praxis: Research Theory and Epistemology in Feminist Sociology, London, New York, Routledge, 1990, p. 103-112.

REINHARZ, Shulamit, Feminist Methods in Social Research, Oxford, Oxford University Press, 1992. ROOKE, Alison, "Queer in the Field: On Emotions, Temporality and Performativity in Ethnography", in BROWNE, Kath, NASH, Catherine J. (eds.), Queer Methods and Methodologies: Intersecting Queer Theories and Social Science Research, Farnham, Burlington, Ashgate Publishing, 2010, p. 25-40.

RUSSO, Vito, The Celluloid Closet: homosexuality in the movies, New York, Harper \& Row, 1981. SEDGWICK, Eve Kosofsky, Epistemology of the Closet, Hemel Hempstead, Harvester Wheatsheaf, 1991.

SILVERMAN, Kaja, The Acoustic Mirror: the female voice in psychoanalysis and cinema, Bloomington, Indiana University Press, 1988.

SKEGGS, Beverley, (ed.), Feminist Cultural Theory: Process and Production, Manchester, New York, Manchester University Press, 1995.

SKEGGS, Beverley, Formations of Class and Gender: Becoming Respectable, London, Sage Publications, 1997.

SOLIE, Ruth A. (ed.), Musicology and Difference: Gender and Sexuality in Music Scholarship, Berkeley, California University Press, 1993.

STACEY, Jackie, Star Gazing: Hollywood Cinema and Female Spectatorship, London, New York, Routledge, 1994.

STANLEY, Liz, "Feminist Praxis and the Academic Mode of Production", in STANLEY, Liz (ed.), Feminist Praxis: Research Theory and Epistemology in Feminist Sociology, London, New York, Routledge, 1990, p. 3-19.

STANLEY, Liz, The Auto/Biographical I: The Theory and Practice of Feminist Auto/Biography, Manchester, New York, Manchester University Press, 1993.

TAYLOR, Jodie, Playing it Queer: Popular Music, Identity, and Queer World-Making, Berlin, Frankfurt, Oxford, New York, Peter Lang, 2012.

THORNTON, Sarah, Club Culture: music, media, and subcultural capital, Hanover, University Press of New England, 1995. 
THORNTON, Sarah, "General Introduction", in GELDER, Ken, THORNTON, Sarah (eds.), The Subcultures Reader, London, New York, Routledge, 1997, p. 1-7.

TIERNEY, William G., Academic Outlaws: Queer Theory and Cultural Studies in the Academy, California, Sage Publications, 1997.

WHITELEY, Sheila, RYCENGA, Jennifer (eds.), Queering the Popular Pitch, New York, Abingdon, Routledge, 2006.

WHITELY, S., Women and Popular Music: Sexuality, Identity, and Subjectivity, New York, Routledge, 2004.

WHITELEY, Sheila (ed.), Sexing the Groove: Popular Music and Gender, London, Routledge, 1997.

WISE, Sue, "Becoming a feminist social worker", in STANLEY, Liz (ed.), Feminist Praxis: Research Theory and Epistemology in Feminist Sociology, London, New York, Routledge, 1990, p. 236-249.

\section{NOTES}

1. Field-notes, December 2003.

2. Field-notes, February 2004.

3. Starting with Susan McClary's seminal Feminine Endings: Music, Gender, and Sexuality, Minneapolis, University of Minnesota Press, 1991, anthologies addressing this issue followed: BARKIN, Elaine, HAMESSLEY, Lydia (eds.), Audible Traces: Gender, Identity, and Music, Zurich, Carciofoli, 1999; COOK, Susan C., TSOU, Judy S. (eds.), Cecilia Reclaimed: Feminist Perspectives on Gender and Music, Illinois, Illinois University Press, 1994; BRETT, Philip, WOOD, Elizabeth, THOMAS, Gary C. (eds.), Queering the Pitch: The New Gay and Lesbian Musicology, New York, London, Routledge, 1994; SOLIE, Ruth A. (ed.), Musicology and Difference: Gender and Sexuality in Music Scholarship, Berkeley, California University Press, 1993.

4. Queer musicologists Joke Dame ("Unveiled Voices: Sexual Difference and the Castrato", in BRETT, Philip, WOOD, Elizabeth, THOMAS, Gary C. (eds.), op. cit., p. 139-153), Linda Austern ("No Women Are Indeed: The Boy Actor as Vocal Seductress in Late Sixteenthand Early Seventeenth- Century English Drama", in DUNN, Leslie C., JONES, Nancy A. (eds.), Embodied Voices: Representing Female Vocality in Western Culture, Cambridge, Cambridge University Press, 1994, p. 83-102) and Wayne Koestenbaum (The Queen's Throat: Opera, Homosexuality, and the Mystery of Desire, New York, Vintage Books, 1994) configure the idea of sexuality in their work through an investigation of how gendered forms of signifying heterosexual desire can be subverted for a queer reception and performance. Also see: WHITELEY, Sheila (ed.), Sexing the Groove: Popular Music and Gender, London, Routledge, 1997.

5. Some work of course did conduct empirical work on queer cultures, which I shall discuss later on: HALBERSTAM, Judith, In a Queer Time and Place: Transgender Bodies, Subcultural Lives, New York, London, New York University Press, 2005, explores the relationship between drag-king cultures and punk/rock; or Mitchell Morris's "Reading as an Opera Queen" (in SOLIE, Ruth A. (ed.),op. cit., p. 184-200) investigates the gay male culture that surrounds the opera/diva through ideas of aesthetics, life-style, and ideology. 
6. The MLGC's growing success has taken them on international tours since 2007, including Europe and North America.

7. Attinello studied five different LGBT choirs in Los Angeles, San Francisco and Chicago. Cf. ATTINELLO, Paul, "Authority and Freedom: toward a sociology of Gay Choruses", in BRETT, Philip, WOOD, Elizabeth, THOMAS, Gary C. (eds.), op. cit., p. 315-346.

8. Attinello provides a full appendix of the questionnaires he handed out to gather information starting from the basic personal profile (age/gender/race/sexual orientation/music degree) to the more "complicated" and "opinion" based (reasons for joining/reasons for staying). Cf. Ibid., p. 335-344.

9. Ibid., p. 324-325.

10. Cf. TAYLOR, Jodie, Playing it Queer: Popular Music, Identity, and Queer World-Making, Berlin, Frankfurt, Oxford, New York, Peter Lang, 2012; WHITELEY, Sheila, RYCENGA, Jennifer (eds.),Queering the Popular Pitch, New York, Abingdon, Routledge, 2006.

11. BROWNE, Kath, NASH, Catherine J. (eds.), Queer Methods and Methodologies: Intersecting Queer Theories and Social Science Research, Farnham, Burlington, Ashgate Publishing, 2010, and BOELLSTORFF, Tom, "Queer Techne: Two Theses on Methodology and Queer Studies", in BROWNE, Kath, NASH, Catherine J. (eds.), op. cit., p. 215-230, offers a useful discussion on queer as a methodology.

12. Cf. ROOKE, Alison, "Queer in the Field: On Emotions, Temporality and Performativity in Ethnography", in BROWNE, Kath, NASH, Catherine J. (eds.), op. cit., p. 25-40; JACKMAN, Michael Connors, "The Trouble with Fieldwork: Queering Methodologies", in BROWNE, Kath, NASH, Catherine J. (eds.), op. cit., p. 113-128.

13. Cf. GORMAN-MURRAY, Andrew, et al., "Queer(ing) Communication in Research Relationships: A Conversation about Subjectivities, Methodologies and Ethics", in BROWNE, Kath, NASH, Catherine J. (eds.), op. cit., p. 97-112; HOLMAN JONES, Stacy, ADAMS, Tony E., "Autoethnography is a Queer Method", in BROWNE, Kath, NASH, Catherine J. (eds.), op. cit., p. 195-214.

14. Cf. WHITELEY, Sheila, RYCENGA, Jennifer (eds.), op. cit.

15. Cf. JACKMAN, Michael Connors, loc. cit.

16. DeNORA, Tia, Music in Everyday Life, Cambridge, Cambridge University Press, 2000; FINNEGAN, Ruth, Hidden Musicians: Music-Making in an English Town, Cambridge, Cambridge University Press, 1989 rep. 2007.

17. DeNORA, Tia, op. cit., p. $x$.

18. Ibid.

19. FINNEGAN, Ruth, op. cit., p. 297.

20. Ibid., p. 305.

21. Ibid., p. 7.

22. Ibid., p. 11.

23. Cf. SEDGWICK, Eve Kosofsky, Epistemology of the Closet, Hemel Hempstead, Harvester Wheatsheaf, 1991; DUBERMAN, Martin B., VICINUS, Martha, CHAUNCEY, George (eds), Hidden from History: reclaiming the Gay and Lesbian Past, London, New York, Meridian Books, 1989; RUSSO, Vito, The Celluloid Closet: homosexuality in the movies, New York, Harper \& Row, 1981; BROWN, Michael P., Closet Space: Geographies of Metaphor from the Body to the Globe, London, New York, Routledge, 2000. 
24. Regarding academic life of queers, see TIERNEY, William G., Academic Outlaws: Queer Theory and Cultural Studies in the Academy, California, Sage Publications, 1997.

25. DeNORA, Tia, op. cit., p. $x$.

26. Field-notes, December 2003.

27. COFFEY, Amanda, The Ethnographic Self: fieldwork and the representation of identity, London, California, New Delhi, Sage Publications, 1999, p. 68.

28. See MARKS, Laura U., Touch: Sensuous Theory and Multisensory Media, Minneapolis, Minnesota University Press, 2002.

29. MALBON, Ben, Clubbing: Dancing, Ecstasy and Vitality, London, New York, Routledge, 1999, p. 84.

30. THORNTON, Sarah, Club Culture: music, media, and subcultural capital, Hanover, University Press of New England, 1995, p. 65.

31. Vanilla's website for example provides DJ profiles which state their availability ("single", "happily attached", etc.) along with their interests. Their message boards are often filled with discussions "who fancies who", and even acts as a on-line dating site.

32. Field-notes, January 2004.

33. By using the word "gaze", here I am referring to some of the discussions on subjectivity, identity and spectatorship by feminist film theorists like STACEY, Jackie, Star Gazing: Hollywood Cinema and Female Spectatorship, London, New York, Routledge, 1994; MULVEY, Laura, Visual and other Pleasures, Basingstoke, Macmillan, 1989; SILVERMAN, Kaja, The Acoustic Mirror: the female voice in psychoanalysis and cinema, Bloomington, Indiana University Press, 1988.

34. Feminist ethnographies place an importance on, if not often centralise the analysis of the self in relation to fieldwork by questioning the role of the researcher/theorist in relation to power and knowledge-production; hence feminist ethnographers have argued that analysis of the self needs equal amounts of theoretical attention as the collected data. See COFFEY, Amanda, op. cit.; SKEGGS, Beverley, Formations of Class and Gender: Becoming Respectable, London, Sage Publications, 1997, and id. (ed.), Feminist Cultural Theory: Process and Production, Manchester, New York, Manchester University Press, 1995; STANLEY, Liz, The Auto/Biographical I: The Theory and Practice of Feminist Auto/Biography, Manchester, New York, Manchester University Press, 1993, and id., "Feminist Praxis and the Academic Mode of Production", in STANLEY, Liz (ed.),Feminist Praxis: Research Theory and Epistemology in Feminist Sociology, London, New York, Routledge, 1990, p. 3-19; REINHARZ, Shulamit, Feminist Methods in Social Research, Oxford, Oxford University Press, 1992; WISE, Sue, "Becoming a feminist social worker", in STANLEY, Liz (ed.), Feminist Praxis: Research Theory and Epistemology in Feminist Sociology, op. cit., p. 236-249; FARRAN, Denise, "'Seeking Susan': producing statistical information on young people's leisure", in STANLEY, Liz (ed.), Feminist Praxis: Research Theory and Epistemology in Feminist Sociology, op. cit., p. 91-102; PUGH, Anne, "My Statistics and Feminism - A True Story", in STANLEY, Liz (ed.), Feminist Praxis: Research Theory and Epistemology in Feminist Sociology, op. cit., p. 103-112; KONDO, Dorinne K., Crafting Selves: Power, Gender and Discourses of Identity in a Japanese Workplace, Chicago, University of Chicago Press, 1990; GRIFFITHS, Vivienne, "Using Drama to Get at Gender", in STANLEY, Liz (ed.), Feminist Praxis: Research Theory and Epistemology in Feminist Sociology, op. cit., p. 221-235; POLAND, Fiona, "Breaking the Rules: Assessing the Assessment of a Girls' Project", in STANLEY, Liz (ed.), Feminist Praxis: Research Theory and Epistemology in Feminist Sociology, op. cit., p. 159-171; HAGGIS, Jane, "The 
Feminist Research Process: Defining a Topic", in STANLEY, Liz (ed.), Feminist Praxis: Research Theory and Epistemology in Feminist Sociology, op. cit., p.67-79. See also HAMMERSLEY, Martyn, What is Wrong with Ethnography?, New York, Routledge, 1993, for more general problems relation to practical research.

35. See also KULICK, Don, WILLSON, Margaret (eds.), Taboo: Sex, Identity, and Erotic Subjectivity in Anthropological Fieldwork, London, New York, Routledge, 1995, an anthology which deals precisely with the tenuous position of the researcher in a sexualized field. Anthropologist Don Kulick argues in the introduction that "erotic subjectivity does things. It performs, or, rather, can be made to perform, work. And one of the many types of work it can perform is to draw attention to the conditions of its own production" (p. 5).

36. McKEGANEY, Neil P., BARNARD, Marina, Sex work on the streets: prostitutes and their clients, Buckingham, Open University Press, 1996.

37. HUMPHREYS, Laud, "The Sociologist as Voyeur", in GELDER, Ken, THORNTON, Sarah (eds.), The Subcultures Reader, London, New York, Routledge, 1997, p. 347-357.

38. POLSKY, Ned, "Research Method, Morality in Criminology", in GELDER, Ken, THORNTON, Sarah (eds.), op. cit., p. 60-72.

39. Humphrey's practical reserach into homosexual activities carried out in tearooms overcomes such methodological problems by ensuring his own anonymity - "passing as deviant" as he states - during the initial part of his research: "shorn of pastoral contacts and unwilling to use professional credentials, I had to enter the subculture as would any newcomer and to make contact with respondents under the guise of being another gay guy". HUMPHREYS, Laud, "The Sociologist as Voyeur", in GELDER, Ken, THORNTON, Sarah (eds.), op. cit., p. 233.

40. BOLTON, Ralph, "Tricks, friends and lvoers: Erotic Encounters in the Field", in KULICK, Don, WILLSON, Margaret (eds.), Taboo: Sex, Identity, and Erotic Subjectivity in Anthropological Fieldwork, op. cit., p. 140-167. Bolton's research involves him actively participating in the sexual activities within the Belgian gay community and seeking information "post-coitally". In his case, cruising in the gay saunas was part of his search for informants, and he built trust with his informants through his sexual relationship to them.

41. HANKIN, Kelly, The Girls in the Back Room: Looking at the Lesbian Bar, Minneapolis, University of Minnesota Press, 2002.

42. MALBON, Ben, op. cit., p. 84.

43. BELL, David, BINNIE, Jon, Sexual Citizen: Queer Politics and Beyond, Cambridge, Oxford, Malden, Polity Press, 2000, p. 87.

44. LIIMOLA, Heikki, "Some notes on choral singing", in POTTER, John (ed.), The Cambridge Companion to Singing, Cambridge, Cambridge University Press, 2000, p. 151.

45. DE CERTEAU, Michel, GIARD, Luce, MAYOL, Pierre, The Practice of Everyday Life, Volume 2: Living and Cooking, Trans., Timothy J. Tomasik, Minneapolis, University of Minnesota Press, 1998, p. 253, emphasis in original.

46. ABRAHAMS, Roger D., "Ordinary and Extraordinary Experience", in TURNER, Victor W., BRUNER, Edward M. (eds.), The Anthropology of Experience, Urbana, Chicago, University of Illinois Press, 1986, p. 60.

47. DE CERTEAU, Michel, GIARD, Luce, MAYOL, Pierre, op. cit., p. 251-252. 


\section{ABSTRACTS}

Based on my fieldwork experiences for a research I conducted in Manchester with the Manchester Lesbian and Gay Chorus (MLGC) between 2003 and 2005, this article demonstrates the usefulness of ethnographical research when investigating issues surrounding music and sexuality. The article suggests that ethnographies can be used as a queer mode of analyzing music. To explore this idea, I begin by examining some of the practical research problems I faced at the onset of my fieldwork, and suggest how these reflect the possible reasons behind conceptual problems surrounding the study of music and sexuality. By discussing how I overcame these problems through joining the MLGC as a soprano engaged in participant observation and qualitative research methods, I argue that ethnographies can loosen what can be a restrictive theoretical connection between music and the idea of "queerness" as being about the subcultural consumption of sexuality/musicality through a form of erotic sociality. By studying the everyday and "mundane", I suggest that ethnographies can allow us to reconceptualise ways in which music connects the cultural and social politics of sexuality. Therefore, this article presents ethnographical research as a queer methodology for the analysis of music, one which moves beyond theoretical questions of gender and the erotic and instead, moves towards the practices of everyday life. The purpose of the piece is to urge more empirical research to be undertaken in studies of music and sexuality in order to bring queer theory and music closer together.

Basé sur les expériences que j'ai pu faire lors d'un travail de terrain réalisé pour une étude menée entre 2003 et 2005 sur le Choeur Lesbien et Gay de Manchester, cet article se propose d'analyser l'utilité de la recherche ethnographique quand on s'intéresse aux rapports entre musique et sexualité. Je cherche ici à montrer que les enquêtes ethnographiques peuvent constituer une méthode queer d'analyse de la musique. Je présente tout d'abord les difficultés pratiques que j'ai rencontrées au début de mon travail de terrain, en montrant que celles-ci peuvent peut-être expliquer les problèmes conceptuels qui se posent lorsque l'on étudie ainsi la question du rapport entre musique et sexualité. Je présente ensuite la manière dont j'ai pu surmonter ces problèmes, en rejoignant le choeur en tant que soprane. Autrement dit: en pratiquant l'observation participante, usant donc de méthodes qualitatives. Je montre de cette façon que les enquêtes ethnographiques peuvent permettre d'interroger la connexion établie théoriquement entre la musique et l'idée du queer, qui peut apparaître comme restrictive, dans la mesure où elle considère que ce type de consommation subculturelle de musicalité et de sexualité relève d'une forme de sociabilité érotique. En étudiant le quotidien dans sa «banalité », je montre que les études ethnographiques peuvent nous permettre de reconceptualiser les liens qui attachent la musique aux idéologies et discours portant sur la sexualité. Ainsi, cet article présente la recherche ethnographique comme une méthode queer d'analyse de la musique, qui se déplace du champ des questions théoriques portant sur le genre et l'érotisme à celui des pratiques quotidiennes. Son objectif est d'encourager le développement de la recherche empirique dans le domaine des études sur la musique et la sexualité, pour permettre de mieux rapprocher la théorie queer de la musique. 
INDEX

Mots-clés: ethnographie, féminisme, musique populaire, ethnicité, sexualité, théorie queer, subcultures

Keywords: ethnography, feminism, popular music, raciality, sexuality, queer theory

\section{AUTHOR}

\section{ESPERANZA MIYAKE}

Dr. Esperanza Miyake currently teaches Media Studies at Liverpool John Moores University, including the Mass Communications summer programme. Her PhD thesis was on Queer Ethnographies of Music and Sexuality. She has and continues to present, publish and review works on popular culture, music, and race/raciality, particularly in relation to sexuality. She is the co-editor (with Dr. Adi Kuntsman) of Out of Place: Interrogating Silences in Queerness/Raciality (Raw Nerve, 2008). She is the author of the award-winning essay, "My, is that Cyborg a Little Queer?" (IJWS, 2004). 